\title{
Insight into the Mechanisms of Combined Toxicity of Single-Walled Carbon Nanotubes and Nickel lons in Macrophages: Role of P2X Receptor
}

\author{
Xuejing Cui, ${ }^{\dagger, \dagger}$ Bin Wan, ${ }^{* \dagger, \dagger}$ Liang-Hong Guo, ${ }^{* \dagger, \downarrow, \S}$ Yu Yang, ${ }^{\dagger}$ and Xiaomin Ren ${ }^{\dagger, \ddagger}$ \\ ${ }^{\dagger}$ State Key Laboratory of Environmental Chemistry and Ecotoxicology, Research Center for Eco-Environmental Sciences, Chinese \\ Academy of Sciences, Beijing 100085, China \\ \#University of Chinese Academy of Sciences, Beijing 100049, China \\ ${ }^{\S}$ Institute of Environment and Health, Jianghan University, Wuhan, Hubei 430056, China
}

Supporting Information

\begin{abstract}
Coexistence of nanomaterials and environmental pollutants requires in-depth understanding of combined toxicity and underlying mechanism. In this work, we found that coexposure to the mixture of noncytotoxic level of single-walled carbon nanotubes (SWCNTs) $(10 \mu \mathrm{g} / \mathrm{mL})$ and $\mathrm{Ni}^{2+}(20 \mu \mathrm{M})$ induced significant cytotoxicity in macrophages. However, almost equal amount of intracellular $\mathrm{Ni}^{2+}$ was detected after $\mathrm{Ni}^{2+}$ /SWCNT coexposure or $\mathrm{Ni}^{2+}$ single exposure, indicating no enhanced cellular uptake of $\mathrm{Ni}^{2+}$ occurred. SDS-PAGE analysis revealed $50 \%$ more SWCNTs retained in $\mathrm{Ni}^{2+} /$ SWCNT exposed cells than that with SWCNT exposure alone, regardless of the exposure sequence (coexposure, $\mathrm{Ni}^{2+}$ pre- or post-treatment), suggesting inhibited SWCNT

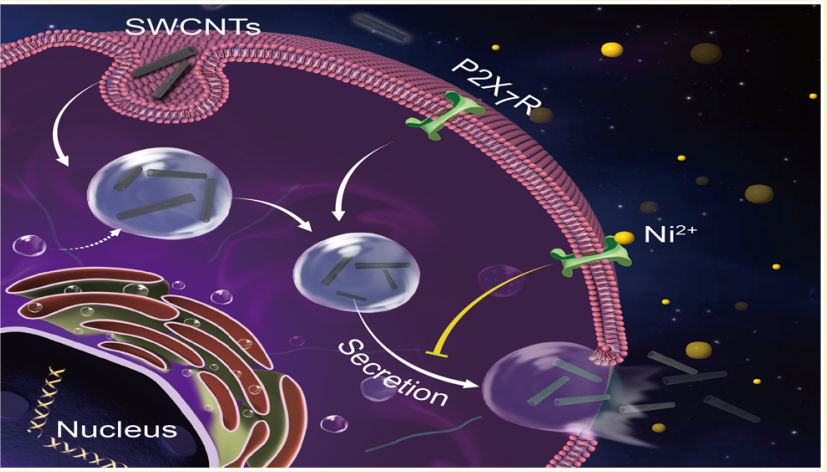
exocytosis by $\mathrm{Ni}^{2+}$. The increased cellular dose of SWCNTs could quantitatively account for the elevated toxicity of $\mathrm{Ni}^{2+} / \mathrm{SWCNT}$ mixture to cells. It was then found that agonist (ATP) and antagonist (o-ATP) of $\mathrm{P} 2 \mathrm{X}_{7} \mathrm{R}$ could regulate intracellular SWCNT amount and the cytotoxicity accordingly. In addition, inhibition of $\mathrm{P} 2 \mathrm{X}_{7} \mathrm{R}$ by $\mathrm{P} 2 \mathrm{X}_{7}$-targeting siRNA diminished the inhibitory effect of $\mathrm{Ni}^{2+}$. It was therefore concluded that $\mathrm{Ni}^{2+}$ impeded SWCNT exocytosis by inhibiting $\mathrm{P}_{2} \mathrm{X}_{7} \mathrm{R}$, leading to higher intracellular retention of SWCNTs and elevated cytotoxicity. Our work identified exocytosis inhibition as an important mechanism for SWCNT/Ni ${ }^{2+}$ toxicity, and revealed the crucial role of $\mathrm{P} 2 \mathrm{X}_{7} \mathrm{R}$ in mediating such inhibitory effect.
\end{abstract}

\section{INTRODUCTION}

Chemicals released into the environment usually coexist with other environmental pollutants as complex mixtures. ${ }^{1-3}$ Concurrent or sequential human exposure to these chemicals dictates the necessity of risk assessment of chemical mixtures. From both the public health and regulatory perspectives, combined toxic effects among mixture components are of particular concerns. Recently, the rapid development of nanotechnology has brought about large amount of nanomaterials that not only improve the quality of life but also raise great concerns on their potential risks on environment and human health. It has been demonstrated that coexposure of some nanomaterials and contaminants induce altered toxicity in living organisms, and the interactive outcomes generally fall into the following three categories. First of all, copresence of nanomaterials and contaminants results in no increased toxicity. ${ }^{4}$ Second, nanomaterials alleviate the toxicity of contaminants compared to the exposure of individual contaminant. $^{5-7}$ The lowered toxicity is often interpreted by the adsorption of contaminants on nanomaterials and consequently reduced bioavailability of contaminants in living organisms. Third, of the most importance and environmental significance, nanomaterials aggravate the toxicity of contaminants in living organisms. This combined toxicity has been observed in binary mixtures composed of either fullerene $\mathrm{C}_{60}$ or nano- $\mathrm{TiO}_{2}$ and a variety of chemicals such as PAHs, PBDEs, ${ }^{10}$ TBT, ${ }^{11}$ and heavy metals. ${ }^{12,13}$ In most of the studies, the combined toxicity is attributed to the so-called "Trojan Horse" effect of nanomaterials, in which they facilitate the ingestion of contaminants by the organisms, increase the cellular dose and therefore amplify the deleterious effects of these toxicants to organisms. The mechanism is also applied to explain the combined effects of carbon nanotubes (CNTs) and a variety of contaminants. ${ }^{14-18}$ In an alternative mechanism, $\mathrm{TiO}_{2}$ nanoparticles were shown to accelerate the biotransfor-

Received: August 1, 2016

Revised: October 14, 2016

Accepted: October 17, 2016

Published: October 17, 2016 
mation of pentachlorophenol to more toxic metabolites, thus enhance the overall toxicity. ${ }^{19}$ These studies have made great progress in understanding the impacts of nanomaterials on the toxicity of environmental contaminants. However, the alteration of nanomaterials toxicity by the chemical contaminant in the mixtures is mostly ignored, and deserves equal attention.

In recent years, single-walled carbon nanotubes (SWCNTs), due to their unique physical, chemical, and electronic properties, have been widely used in the fields of biomedicine, biotechnology, and electronics. ${ }^{20,21}$ With ever increasing range of applications and production rates, SWCNTs will inevitably enter the environment during their life circle. Lines of evidence revealed that SWCNTs could enter organisms via the respiratory or intestinal tract and accumulate in living organisms for as long as three months. ${ }^{22-25}$ In vivo studies showed that CNTs through inhalation (intratracheal instillation and pharyngeal aspiration) could induce acute inflammation, progressive granulomas and fibrosis in animals. ${ }^{25,26}$ In vitro, CNTs were shown to cause lower cell viability and depressed cell proliferation in human lung-tumor and keratinocyte cells $^{27,28}$ and decrease in cell-adhesion ability and altered cellcycle regulation in embryo kidney cells. ${ }^{29}$ The toxicities have also been detected in other cell types, namely mesenchymal stem cells, ${ }^{30}$ and epithelial cells. ${ }^{31}$ Most recently, our studies and others showed that SWCNTs could readily enter macrophages and interfere with the biogenesis and gene expression of lysosome, proteasome and mitochondrial respiration chains, inducing inflammatory response, ${ }^{32}$ resulting in suppressed engulfing function of primary monocytes/ macrophages. 33,34

Nickel is ubiquitously present in the environment, and the exposure to low doses of $\mathrm{Ni}$ compounds is unavoidable. In the field of nanotechnology, nickel is often used as a catalyst for the synthesis of commercial SWCNTs, or as a coating material on the surface of nanoparticles, which lead to the coexistence of nanoparticles and nickel. The presence of nickel in these products might be toxic as it can form reactive oxygen species (ROS) that is detrimental to cells. As a Group I carcinogen to humans, ${ }^{35}$ environmental nickel has already raised health concern stemming from the knowledge of its toxicity and pathogenic properties derived from occupational epidemiology and animal studies including carcinogenicity, genotoxicity, and neurotoxicity. ${ }^{36-38}$ Especially, nickel ions (II) were shown to inhibit the activity of an important purinergic receptor, $\mathrm{P} 2 \mathrm{X}_{7} \mathrm{R},{ }^{39,40}$ which mediates the production and release of inflammasomes. ${ }^{41,42}$ Most importantly, this receptor was reported to mediate the secretion of lysosomes, ${ }^{43,44}$ where most carbonaceous nanomaterials including SWCNTs are localized after cellular internalization. ${ }^{45-47}$ Normally, at the cellular level, the toxic properties and extent of SWCNTs depend on the amount of SWCNTs inside cells, which are determined by a variety of cell processes including exocytosis. It is possible that SWCNTs and other contaminants such as nickel ions interact with each other, resulting in altered toxicological profile. Thus, we hypothesized that nickel ions might interfere with toxicokinetics and thus the toxicity of SWCNTs.

To test the hypothesis, monocytic/macrophage cells were employed based on two considerations. Macrophages are abundant in $\mathrm{P}_{2} \mathrm{X}_{7} \mathrm{R}$ expression. ${ }^{48}$ They are also pivotal players in both innate and adaptive immunity. As a part of the first line of defense against invading foreign substances including nanoparticles, macrophages are the primary target for nano- particle toxicity. ${ }^{32,34}$ Therefore, we compared the toxicity of SWCNTs and nickel ions both alone and in combination on macrophage survival, and investigated the molecular mechanisms underlying the combined effects.

\section{MATERIALS AND METHODS}

Materials. The murine macrophage cell line Raw264.7 cells (ATCC: TIB-71) and human monocytic cell line THP-1 cells (ATCC: TIB-202) were acquired from American Type Culture Collection. All ingredients for the culture media were purchased from Gibco, Invitrogen (UK). SWCNTs (CNTs purity $>95 \%$, SWCNT purity $>90 \%$, ash $<5$ wt $\%$ ) synthesized by chemical vapor deposition (CVD) method were originally obtained from Chengdu Organic Chemicals Co., Ltd. (SiChuan, China) in high purity. The detailed information can be found on the company Web site: http://www. timesnano.com/. The Alexa Fluor488 probe was purchased from Invitrogen (USA). Nickel chloride, ATP (adenosine 5'triphosphate), oATP (oxidized adenosine 5'-triphosphate) and Hoechst 33342 were purchased from Sigma-Aldrich (USA). Rabbit anti-mouse $\mathrm{P} 2 \mathrm{X}_{7}$ and $\beta$-actin antibody were purchased from Cell Signaling Technology (U.S). IRDye 680RD Goat anti-Rabbit IgG (secondary antibody) was from LI-COR company (U.S.).

Preparation of Single-Walled Carbon Nanotubes. Preparation of SWCNTs solution was performed according to the procedure described previously. ${ }^{32}$ In detail, $10 \mathrm{mg}$ SWCNTs were suspended in $40 \mathrm{~mL}$ of a 3:1 mixture of concentrated $\mathrm{H}_{2} \mathrm{SO}_{4} / \mathrm{HNO}_{3}$ in a $200 \mathrm{~mL}$ flask and sonicated in a water bath (KQ-500DV, $40 \mathrm{kHz}$ ) for $24 \mathrm{~h}$ at $40-50{ }^{\circ} \mathrm{C}$. The resultant suspension was then diluted with $200 \mathrm{~mL}$ deionized water and filtered through a membrane (pore size $0.22 \mu \mathrm{m}$ ), followed by washing with $50 \mathrm{~mL}$ deionized water on the membrane. The SWCNTs were resuspended in sterilized deionized water at a concentration of $1 \mathrm{mg} / \mathrm{mL}$ with brief sonication (KQ-500DV, $40 \mathrm{kHz}$ ). The acid-functionalized SWCNTs suspension was black, well dispersed, and had neutral $\mathrm{pH}$.

Characterization of SWCNTs. The morphology and structure were imaged with a HitachiH-7500 transmission electron microscope (TEM, Tokyo, Japan). Specifically, the sample was diluted to $0.5 \mathrm{mg} / \mathrm{mL}$ in water. Thereafter, the suspension was precipitated onto a copper net and dried at room temperature and then subject to TEM examination (Figure S1). In addition, the infrared spectra of SWCNTs were collected by using a FT-IR spectrometer (JASCO, Inc., Easton, $\mathrm{MD}$ ) (Figure S1). Zeta potential (ZP) and dynamic light scattering of SWCNTs were measured by Zetasizer Nano (Malvern Instruments, Malvern, UK). Raman measurement was performed via using Renishaw Raman spectroscope (Wotton-under-Edge, UK) with excitation wavelength at 532 nm (Figure S1).

Cell Culture and Exposure. Raw264.7 and THP-1 cells were cultured at $37{ }^{\circ} \mathrm{C}$ in fully humidified atmosphere containing $5 \% \mathrm{CO}_{2}$ in complete culture medium (cRPMI) consisting of RPMI-1640 and 10\% heat deactivated fetal bovine serum (FBS) supplemented with $20 \mathrm{mM}$ L-glutamine and 100 $\mathrm{UmL}^{-1}$ penicillin/streptomycin. For all experiments of SWCNTs quantification, cells were seeded in 6-well plates (Corning, U.S.) at a density of $5 \times 10^{5}$ cells $/ \mathrm{mL}$ in cRPMI and allowed to attach for overnight. The stock solution of $1 \mathrm{mg} / \mathrm{mL}$ SWCNTs was prepared by sonicating in a cold water bath (KQ-500DV, $40 \mathrm{kHz}$ ) for $5 \mathrm{~min}$ before usage. Thereafter, the 
stock solutions were diluted in cRPMI to desired concentrations for exposure.

Inductively Coupled Plasma Mass Spectrometry (ICPMS) Analysis of $\mathrm{Ni}^{2+}$. To measure $\mathrm{Ni}^{2+}$ content inside and outside cells, Raw264.7 cells $\left(5 \times 10^{5}\right.$ cells $\left./ \mathrm{mL}\right)$ were treated with $20 \mu \mathrm{M} \mathrm{Ni}^{2+}$ and mixture of $10 \mu \mathrm{g} / \mathrm{mL}$ SWCNTs and 20 $\mu \mathrm{M} \mathrm{Ni}^{2+}$ (brief mixing for $30 \mathrm{~s}$ ) for $24 \mathrm{~h}$. After then, the extracellular supernatants were collected. Meanwhile, the cells were washed three times with $\mathrm{PBS}$ and digested with $\mathrm{HNO}_{3}$ / $\mathrm{H}_{2} \mathrm{O}_{2}$ (1:1). After that, the levels of $\mathrm{Ni}^{2+}$ inside cells and in the supernatant were assessed using the ICP-MS (Agilent 7500). In addition, to detect the absorption of $\mathrm{Ni}^{2+}$ onto SWCNTs in cells, we further centrifuged the cell lysate from mixture treated group to isolate SWCNTs and the $\mathrm{Ni}^{2+}$ amount pelleted with SWCNTs was measured by ICP-MS.

SDS-PAGE and UV-vis-NIR Quantification of SWCNTs in Cells and Supernatants. To quantify SWCNTs amount inside macrophages, the cells were treated with SWCNTs or the mixture of SWCNTs and $\mathrm{Ni}^{2+}$ for indicated times. After treatment, the intracellular SWCNTs were quantified by using SDS-PAGE method, as described previously. ${ }^{49}$ In detail, the cells were lysed with $160 \mu \mathrm{L}$ lysis buffer (1\% SDS, $1 \mathrm{mM}$ $\mathrm{MgCl}_{2}$, and $1 \mathrm{mM} \mathrm{CaCl}$ ) for $3 \mathrm{~min}$, then $20 \mu \mathrm{L}$ cell lysates were subjected to SDS-PAGE electrophoresis on a standard BD Mini Vertical Gel $(10 \times 8 \mathrm{~cm})$ with only $4 \%$ stacking gel as SWCNTs loading substrate. The samples were electrophoresed at $120 \mathrm{~V}$ for $2 \mathrm{~h}$, and SWCNTs would deposit on the loading well forming a dark band. After that, loading wells were sealed with $4 \%$ stacking gel. Next, UMAX scanner was used to scan SWCNTs bands on the gel and the intensity of the bands were analyzed using Gelpro software (Media Cybernetics, U.S.). To ensure the loaded samples were from same cells number, the protein amount of each sample was quantified with BCA protein assay kit (KangWei Co. Ltd., China). Simultaneously, the corresponding supernatant in each treatment group was collected for UV-vis-NIR (Varian Cary 5000, USA) analyses.

SWCNTs Labeling and Tracking within Raw264.7 Cells. To track SWCNTs internalization in macrophages, We labeled SWCNTs with a fluorescent dye Alexa Fluor 488 (SWCNT-Alexa Fluor 488) and then compared the distribution pattern of SWCNTs in cells treated with SWCNTs or SWCNTs $/ \mathrm{Ni}^{2+}$. The cells were exposed to Alexa Fluor 488 labeled SWCNTs for $24 \mathrm{~h}$ or mixture of Alexa Fluor 488 labeled SWCNTs $/ \mathrm{Ni}^{2+}$, and then SWCNTs outside cells was washed off with PBS. The internalization of SWCNTs was performed via confocal laser scanning microscopy (Leica, Mannheim, Germany). The Alexa Fluor 488 labeled SWCNTs was prepared by mixing SWCNTs with an amine-containing fluorescent dye, Alexa Fluor488 cadaverine, and through EDC/ NHS mediation (1:1) in MES buffer, Alexa Fluor 488 was covalently linked with the carboxyl groups of SWCNTs. The labeled SWCNTs were further purified and concentrated by centrifugation at $12000 \mathrm{rpm}$ using ultrafiltration tubes (Millipore, Germany) for 4 cycles and then diluted to the desired concentration before exposure to cells for confocal microscopy imaging.

Flow Cytometric Assay. To further confirm $\mathrm{Ni}^{2+}$ influence on SWCNTs exocytosis, we analyzed fluorescence intensity of Alexa Fluor 488-SWCNTs within cells by using flow cytometer to evaluate the relative amount of intracellular SWCNTs. Raw264.7 cells were incubated with $5 \mu \mathrm{g} / \mathrm{mL}$ Alexa Fluor 488SWCNTs or mixture of $5 \mu \mathrm{g} / \mathrm{mL}$ Alexa Fluor 488-SWCNTs and $20 \mu \mathrm{M} \mathrm{Ni}^{2+}$ for $24 \mathrm{~h}$. The cells were then washed three times with PBS before trypsinizing and resuspended in medium. The fluorescent intensity of Alexa Fluor 488SWCNTs were analyzed using a flow cytometer (BD Biosciences, San Jose, CA) by collecting 10000 events. The data files were saved and analyzed using Cell Quest software (BD Biosciences).

P2X 7 Receptor Silencing. Raw264.7 cells were transfected with small interfering RNA (siRNA) to silence $\mathrm{P} 2 \mathrm{X}_{7}$ receptor expression. $\mathrm{P}_{2} \mathrm{X}_{7} \mathrm{R}$-targetting oligonucleotides were designed and generated from full-length mouse $P 2 X_{7} R$ by Shanghai GeneChem Co., Ltd. (Shanghai, http://www.genechem.com. cn). After testing knockdown efficiencies, stem-loop DNA oligonucleotides were synthesized by Shanghai GeneChem Co. Ltd. (sense, 5' - CCG G GC GGA AAG AGC CTG TTA TCA GCT CGA GCT GAT AAC AGG CTC TTT CCG CTT TTT G-3'; antisense, 5'- AAT TCA AAA AGC GGA AAG AGC CTG TTA TCA GCT CGA GCT GAT AAC AGG CTC TTT CCG C-3') and cloned into the lentivirus-based RNAi vector GV248. A nontargeting stem-loop DNA GV248 vector was also generated for use as a negative control. Lentiviral particles were prepared according to protocol provided by GeneChem Co. Ltd. Raw264.7 cells were then infected with P2X 7 R-RNAilentivirus or negative control virus in the presence of ENI solution (GeneJikai, Shanghai, China) $(\mathrm{MOI}=100)$. Then, the cells were treated with the mixed solution for $10 \mathrm{~h}$ at $37{ }^{\circ} \mathrm{C}$ in fully humidified atmosphere containing $5 \% \quad \mathrm{CO}_{2}$. After removing infection solution, the cells were further cultured in fresh medium for another 2 days. Part of the cells were then collected to extract total RNA for quantitative reverse transcription polymerase chain reaction (QRT-PCR) and proteins for Western blot analyses to confirm the effectiveness of knock-down expression of $\mathrm{P}_{2} \mathrm{X}_{7} \mathrm{R}$. Then, the cells were used for different experiments.

$\mathrm{P}_{2 \mathrm{X}_{7}}$ Receptor Gene Expression and mRNA Transcription. The mRNA levels of $\mathrm{P} 2 \mathrm{X}_{7}$ receptors in cells after $\mathrm{P} 2 \mathrm{X}_{7} \mathrm{R}$ knock-down were measured by real-time RT-PCR (LightCyclerC480, Roche, Germany). The comparative $C_{t}$ method for relative quantification of gene expression $(\Delta \Delta \mathrm{Ct}$ method) was used, and gene expression levels of $\mathrm{P}_{2} \mathrm{X}_{7}$ receptors were normalized to gene expression of GAPDH (as a housekeeping gene control) using the following equation: $\mathrm{P} 2 \mathrm{X}_{7} \mathrm{R}$ mRNA normalized expression $=2^{\left[\Delta \mathrm{Ct}(\mathrm{GAPDH})-\Delta \mathrm{Ct}\left(\mathrm{P} 2 \mathrm{X}_{7} \mathrm{R}\right)\right]}$.

Western Blot Assay. Cell lysates were separated by SDSPAGE with $10 \%$ separation gel. The samples were transferred to polyvinylidene difluoride membrane (Immobilon-P, Millipore, Germany), and the membrane was blocked with $5 \%$ nonfat milk (TBS) and washed three times with TBST (containing $0.1 \%$ Tween 20). Thereafter, the membrane was incubated with primary antibodies (1:1000 dilution) against $\mathrm{P}_{2} \mathrm{X}_{7}$ and $\beta$-actin (Cell Signaling Technology, MA) at $4{ }^{\circ} \mathrm{C}$ for overnight, and then washed with TBST again. The membrane was incubated with corresponding secondary antibody (IRDye 680RD Goat anti-Rabbit, 1:5000 dilutions) for $1 \mathrm{~h}$ at room temperature in the dark, followed by three washes with TBST and two washed with TBS. The bands of target proteins were observed using an Odyssey CLx instrument (LI-COR, U.S.). Quantitative analysis of the band intensities was performed using Gel-pro image software (Media Cybernetics, U.S.).

Cytotoxicity Assay. Cell viability was assessed by an aqueous soluble tetrazolium/formazan assay (WST-1 assay) based on the conversion of a tetrazolium salt into water-soluble formazan product, which is mediated by cellular dehydrogenases present only in living cells. Therefore, the intensity of 
dye converted is directly proportional to the number of living cells. ${ }^{50}$ The cells were exposed to the tested samples at series concentrations. Cells without treatment were set as control. After treatment, the cells were washed with PBS twice and incubated with the WST-1 assay reagents for $2 \mathrm{~h}$ and absorbance was measured at $450 \mathrm{~nm}$ with a Varioskan Flash microplate reader (Varioskan Flash, Thermo Scientific, Waltham, MA). Cell viability was expressed as the percentage of the control group.

Statistical Analysis. Data were expressed as mean \pm SD., and the difference between groups was evaluated using two-tails Student's $t$ test, with the significance level set at $* p<0.05$, **p $<0.01$.

\section{RESULTS AND DISCUSSION}

Combined Toxicity of SWCNTs and Nickel lons (II). Well-dispersed suspension of SWCNTs in aqueous solution was synthesized following the protocol described in the Materials and Methods section. The resulting CNT suspension contains 0.056 wt $\%$ of iron and no nickel and cobalt was detected, as we reported previously. ${ }^{32}$ The approach enables insertion of carboxyl and hydroxyl groups around the sidewalls and at the tips of the SWCNTs, which makes the tubes well dispersed in aqueous medium for days (Figure S1). In addition, hydrodynamic size and surface charge were analyzed by dynamic light scattering assessment (Table 1). Hydrodynamic

Table 1. Hydrodynamic Size (HDS, nm) and Zeta Potential $(\mathrm{ZP}, \mathrm{mV})$ of SWCNTs in Water, Serum-Free Medium (SFM), Serum-Supplemented Medium (SSM)

\begin{tabular}{crcr} 
SWCNTs & \multicolumn{1}{c}{ Water } & SFM & \multicolumn{1}{c}{ SSM } \\
HDS & $86.4 \pm 4.4$ & $1132 \pm 69$ & $112 \pm 6.2$ \\
ZP & $-47.1 \pm 1.6$ & $-23 \pm 0.7$ & $-8.4 \pm 0.2$
\end{tabular}

diameters and surface charges of nanomaterials changed in SSM and SFM compared to water because in serum free medium, the ions would be neutralizing the surface charge of SWCNTs and causes aggregation, but in serum medium, the serum protein would facilitate the dispersion of SWCNTs, resulting lower hydrodynamic size, compared with serum free medium, but still larger than that in water.

Subsequently, we investigated the combined toxicity of SWCNTs and $\mathrm{Ni}^{2+}$. As shown in Figure 1, macrophages did not undergo cell viability loss when exposed to 5 and $10 \mu \mathrm{g} / \mathrm{mL}$ SWCNTs for $24 \mathrm{~h}$, which is consistent with our previous studies showing that $10 \mu \mathrm{g} / \mathrm{mL}$ SWCNTs poses no cytotoxicity on Raw 264.7 cells or murine peritoneal macrophages, as determined by $\mathrm{LDH}$ release, live/dead staining and apoptosis analyses. $^{32,34,47}$ Under the same experimental condition, $20 \mu \mathrm{M}$ $\mathrm{Ni}^{2+}$ was noncytotoxic, but there was about $21 \%$ viability loss when cells were exposed to a mixture of $20 \mu \mathrm{M} \mathrm{Ni}^{2+}$ and 10 $\mu \mathrm{g} / \mathrm{mL}$ SWCNTs (Figure 1). Furthermore, a mixture of $20 \mu \mathrm{g} /$ $\mathrm{mL}$ SWCNTs and $20 \mu \mathrm{M} \mathrm{Ni}^{2+}$ caused approximately $26 \%$ cell death, whereas $20 \mu \mathrm{g} / \mathrm{mL}$ SWCNTs alone induced $14 \%$ cell death, indicating that $\mathrm{Ni}^{2+}$ at $20 \mu \mathrm{M}$ dramatically aggravated the cytotoxicity of SWCNTs by almost 2-fold (Figure 1). The toxicity of SWCNTs and $\mathrm{Ni}^{2+}$ mixture to macrophages is obviously higher than the additive effect of SWCNTs and $\mathrm{Ni}^{2+}$ toxicity alone. The cytotoxicity of $\mathrm{Ni}^{2+}$ with higher concentrations was not further investigated because higher concentrations caused significant cell death (Figure S2). Interestingly, we did not observe any toxicity to macrophages upon

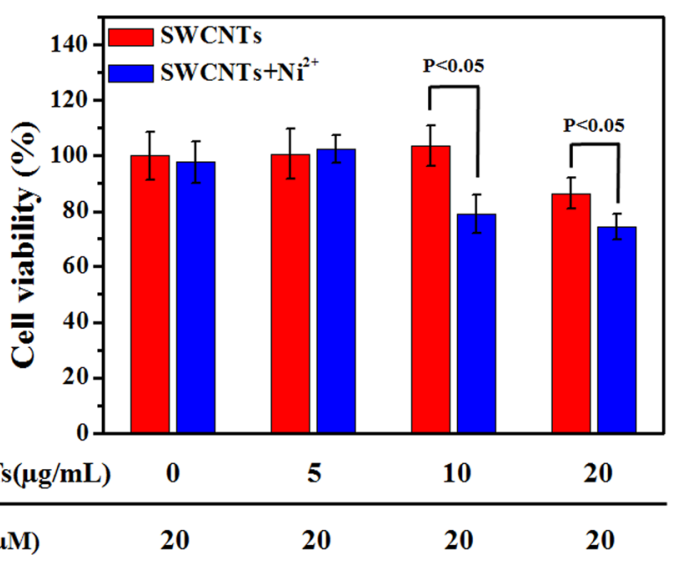

Figure 1. Cell viability after treatment with SWCNTs or $\mathrm{Ni}^{2+}$, alone or in combination. Raw 264.7 cells were exposed to 5, 10, and $20 \mu \mathrm{g} / \mathrm{mL}$ SWCNTs, $20 \mu \mathrm{M} \mathrm{Ni}^{2+}$, and mixture of SWCNTs and $\mathrm{Ni}^{2+}$. Then, the cell viability was determined by WST-1 assay.

SWCNTs $/ \mathrm{Ni}^{2+}$ treatment at lower SWCNTs concentration (5 $\mu \mathrm{g} / \mathrm{mL}$ ) (Figure 1), suggesting that SWCNTs-induced cytotoxicity only occurs when internalized SWCNTs exceed certain threshold. Taken together, these data demonstrated that coexposure of SWCNTs and $\mathrm{Ni}^{2+}$ resulted in elevated toxicity in macrophages.

Nickel lons (II) Quantification by ICP-MS. The above result supports the idea that coexposure of SWCNTs and $\mathrm{Ni}^{2+}$ could lead to elevated toxicity in macrophages. Nonetheless, the underlying mechanism is still unknown. One possibility for the elevated toxicity might be that SWCNTs could act as a carrier to transport more $\mathrm{Ni}^{2+}$ into cells. To address the question, we measured the levels of $\mathrm{Ni}^{2+}$ both in cells and in supernatants by using ICP-MS. As shown in Figure 2, the intracellular $\mathrm{Ni}^{2+}$ amount for SWCNTs $/ \mathrm{Ni}^{2+}$ treatment group was approximately the same to that of $\mathrm{Ni}^{2+}$ treatment group, indicating that the presence of SWCNTs did not change the internal amount of $\mathrm{Ni}^{2+}$ in macrophages. Meanwhile, the $\mathrm{Ni}^{2+}$ contents in the supernatants of these two groups showed similar results as well. In addition, because the $\mathrm{Ni}^{2+}$ could be

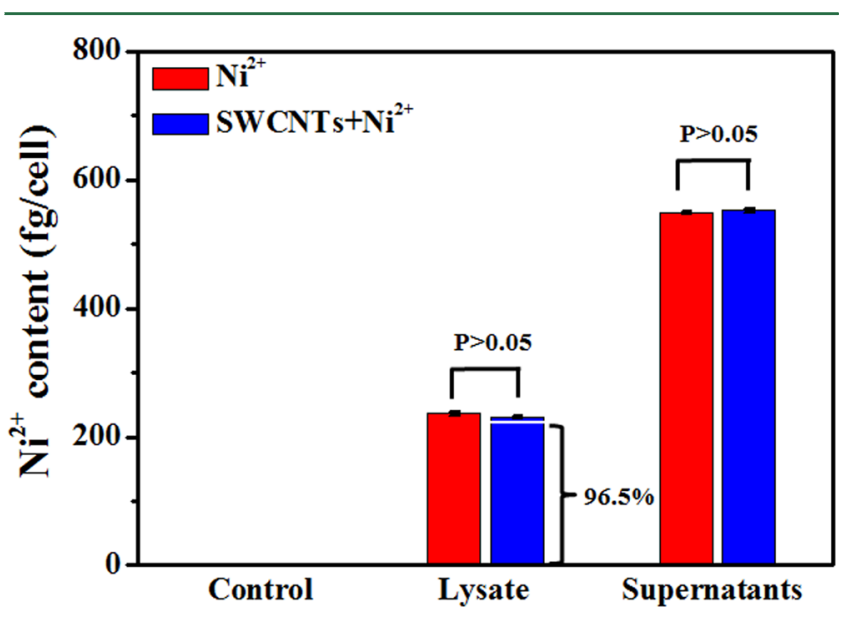

Figure 2. Quantitative analysis of $\mathrm{Ni}^{2+}$ by inductively coupled plasma mass spectrometry (ICP-MS). Raw264.7 cells were treated with 20 $\mu \mathrm{M} \mathrm{Ni}^{2+}$ and mixture of $10 \mu \mathrm{g} / \mathrm{mL}$ SWCNTs and $20 \mu \mathrm{M} \mathrm{Ni}^{2+}$ for 24 h. After then, the cells lysates and the supernatants were analyzed with ICP-MS $(n=3)$. The level of $\mathrm{Ni}^{2+}$ in cells without treatment was set as control. 
A
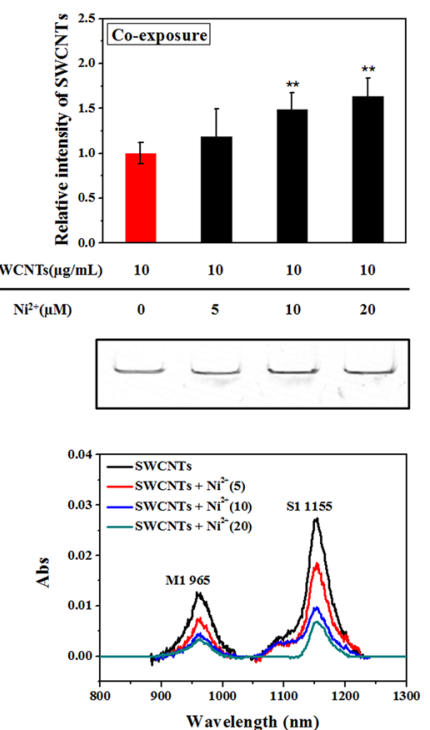

D

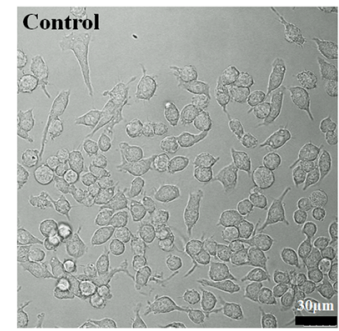

B
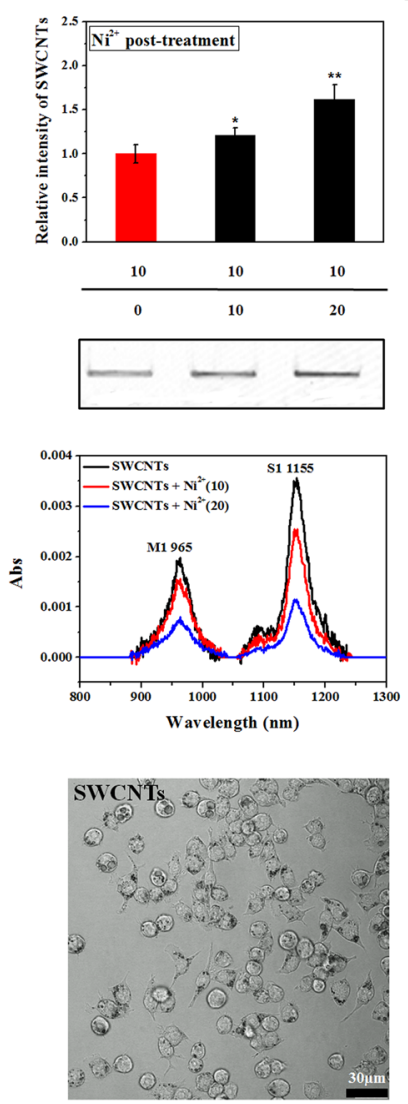

C
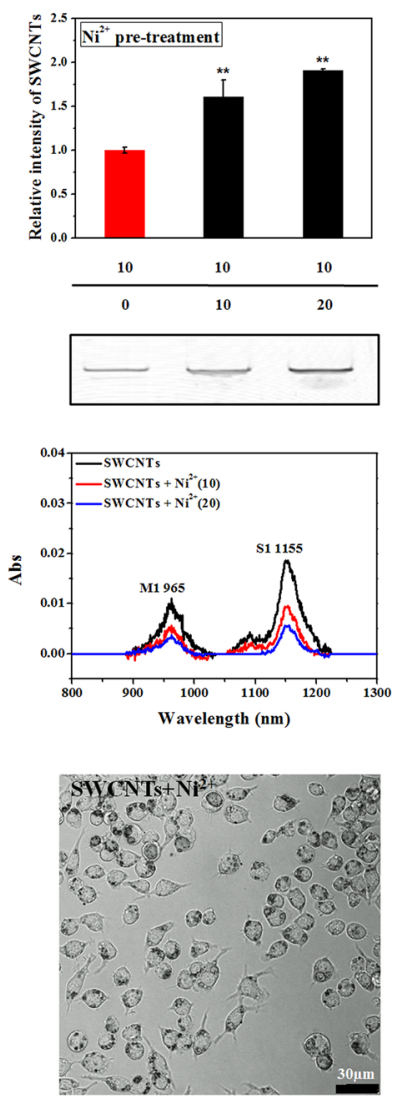

E

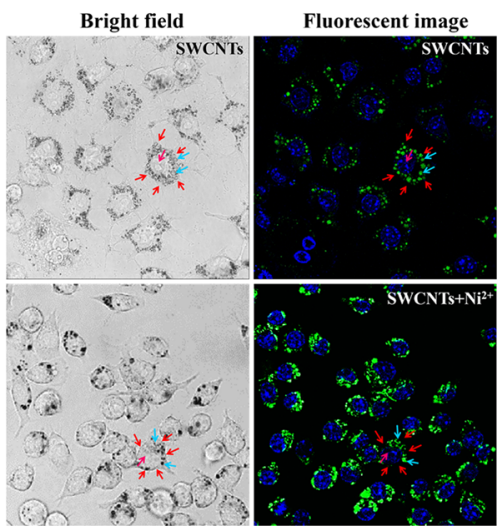

F

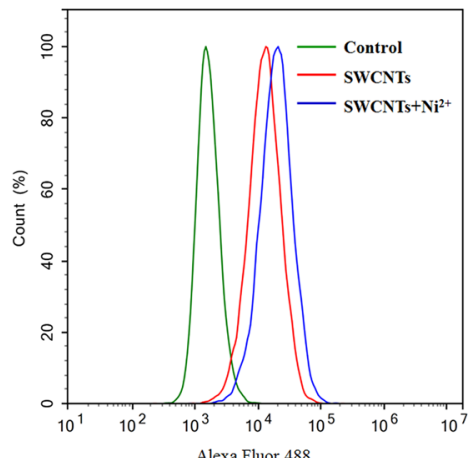

Figure 3. Quantification of SWCNTs in cells and supernatants and the localization pattern of SWCNTs in macrophages upon treatment with SWCNTs or a mixture of SWCNTs and $\mathrm{Ni}^{2+}$. (A) SDS-PAGE gel (numeric data for upper panel and gel image for middle panel) and UV-vis-NIR analyses (lower panel) of SWCNTs amount in macrophages and supernatants after $24 \mathrm{~h}$ coexposure of SWCNTs and Ni ${ }^{2+}$. (B) SDS-PAGE gel and UV-vis-NIR analyses of SWCNTs amount in macrophages and supernatants after the cells were post-treated with $\mathrm{Ni}^{2+}$. Raw264.7 macrophage were exposed to $10 \mu \mathrm{g} / \mathrm{mL}$ SWCNTs for $8 \mathrm{~h}$, followed by removing SWCNTs solution, and further incubated with $10 \mu \mathrm{M}$ and $20 \mu \mathrm{M} \mathrm{Ni}{ }^{2+}$ for $16 \mathrm{~h}$. (C) SDS-PAGE gel and UV-vis-NIR analyses of SWCNTs amount in macrophages and supernatants after the cells were pretreated with $\mathrm{Ni}^{2+}$. Macrophages were pretreated with 10 and $20 \mu \mathrm{M} \mathrm{Ni}^{2+}$ for $16 \mathrm{~h}$, followed by removing Ni ${ }^{2+}$ and incubation with $10 \mu \mathrm{g} / \mathrm{mL}$ SWCNTs for another $8 \mathrm{~h}$. The intensity of the SWCNTs bands was analyzed using Gelpro software $(n=3)$. (D) Representative confocal images of Raw264.7 cells upon exposure to 0 (control), $10 \mu \mathrm{g} / \mathrm{mL}$ SWCNTs, and mixture of SWCNTs $(10 \mu \mathrm{g} / \mathrm{mL})$ and Ni ${ }^{2+}(20 \mu \mathrm{M})$ for $24 \mathrm{~h}$. Scale bar $=30 \mu \mathrm{m}$. (E) Confocal images showing the localization pattern of SWCNT-Alexa Fluor 488 (green) in macrophages (Arrows: Red, cell membrane; pink, cell nucleus; cyan, cytoplasm) and (F) the fluorescence intensity of Alexa Fluor 488 of cells receiving SWCNT-Alexa Fluor 488 or SWCNT-Alexa Fluor 488/Ni ${ }^{2+}$ exposure, as determined by flow cytometry analyses.

adsorbed on SWCNTs to some extent, we detect the adsorption capacity of SWCNTs for $\mathrm{Ni}^{2+}$ and found that only $3.5 \%$ of $\mathrm{Ni}^{2+}$ was adsorbed on SWCNTs but $96.5 \% \mathrm{Ni}^{2+}$ entered cells in free status, which constitute neglectable effect in cell lysate (Figure 2). Together, the combined data ruled out the possibility that the elevated toxicity was caused by increased $\mathrm{Ni}^{2+}$ transportation into cells.

Nickel Ions (II) Inhibits Exocytosis of SWCNTs. After ruling out the possibility that the elevated toxicity of SWCNTs and $\mathrm{Ni}^{2+}$ in macrophages was due to SWCNT-mediated transport of more $\mathrm{Ni}^{2+}$ into cells, we hypothesized another 
A
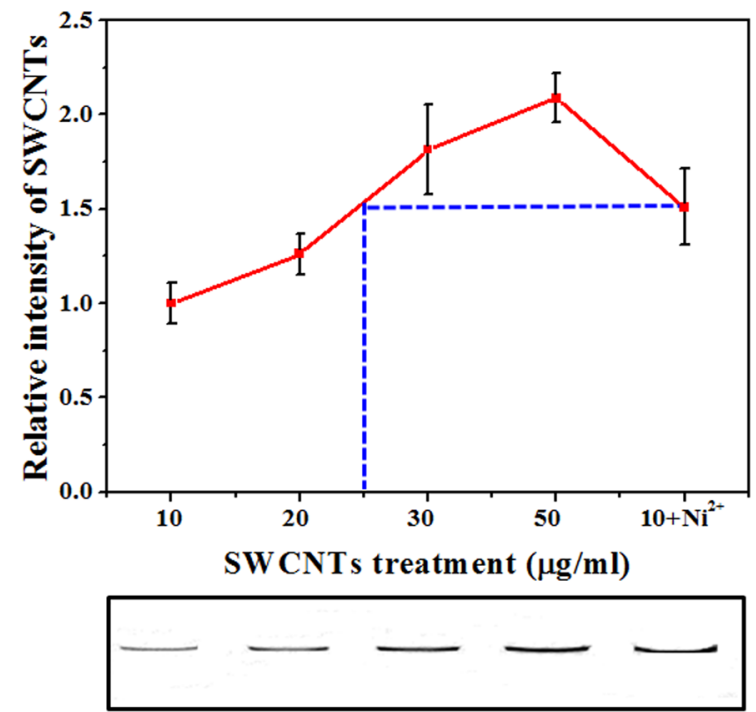

B

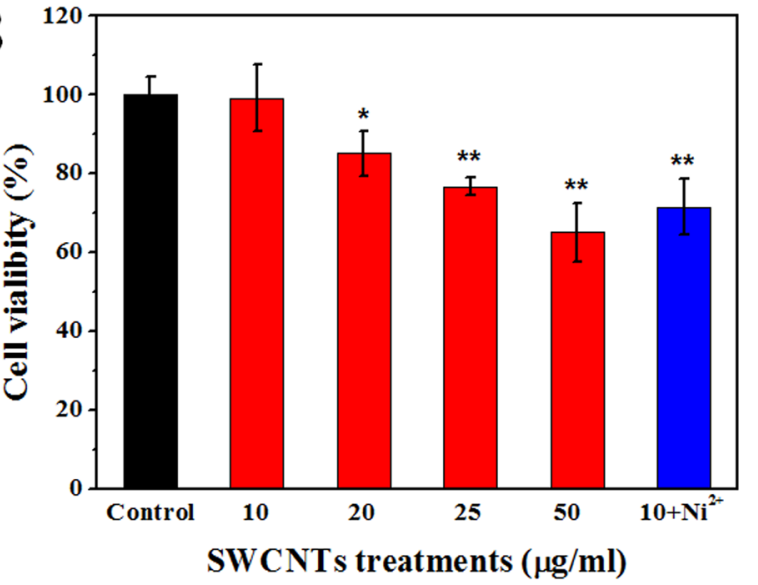

Figure 4. Quantification of intracellular SWCNTs accumulation and reduced viability of macrophages upon exposure to SWCNTs and SWCNTs/ $\mathrm{Ni}^{2+}$. (A) Concentration-dependent increase of intracellular SWCNT accumulation in macrophages exposed to $10,20,30$, and $50 \mu \mathrm{g} / \mathrm{mL}$ SWCNTs alone, and mixture of $10 \mu \mathrm{g} / \mathrm{mL}$ SWCNTs and $20 \mu \mathrm{M} \mathrm{Ni}^{2+}$ for $24 \mathrm{~h}$. Lower panels show corresponding representative SWCNTs bands in gel. The intensity of the dark band of the SWCNTs was analyzed using Gelpro software. (B) Cell viability change of macrophages upon exposure to SWCNTs alone and SWCNTs/Ni ${ }^{2+}$.

possibility that $\mathrm{Ni}^{2+}$ inhibits exocytosis of SWCNTs resulting in increased accumulation of SWCNTs in cells, leading to higher toxicity. To validate the hypothesis, we compared the intracellular SWCNTs in macrophages after exposure of SWCNTs alone or the mixture of SWCNTs $/ \mathrm{Ni}^{2+}$ for $24 \mathrm{~h}$. Simultaneously, the corresponding supernatants were collected for UV-vis-NIR analysis. As showed in Figure 3A, compared to the SWCNTs alone group, coexposure with $\mathrm{Ni}^{2+}$ increased the amount of intracellular SWCNTs (Figure 3A, upper panel) and decreased the extracellular SWCNTs amount (Figure 3A, lower panel) in a $\mathrm{Ni}^{2+}$ concentration-dependent manner, indicating that $\mathrm{Ni}^{2+}$ inhibited SWCNTs exocytosis from cells. However, the significant increase of intracellular SWCNTs after $\mathrm{Ni}^{2+}$ coexposure also raised the question as to whether the increase was due to increased SWCNT uptake or not. To exclude the possibility, the cells were first exposed to SWCNTs for $8 \mathrm{~h}$ so as to take up equal amount of SWCNTs for both treatment groups. Then the SWCNTs solution was removed, and $\mathrm{Ni}^{2+}$ was added to the test group for further incubation for $16 \mathrm{~h}$. Subsequently, we measured the intracellular and extracellular SWCNTs amount by SDS-PAGE and UV-vis-NIR, respectively. Similarly, we found that intracellular SWCNTs (Figure $3 \mathrm{~B}$, upper panel) increased and extracellular SWCNTs (Figure $3 \mathrm{~B}$, lower panel) decreased in a $\mathrm{Ni}^{2+}$ concentration dependent manner as well, which verified the inhibitory effect of $\mathrm{Ni}^{2+}$ on SWCNTs exocytosis from macrophages. Besides, pretreatment of $\mathrm{Ni}^{2+}$ also induced a large increase of intracellular SWCNTs in macrophage cells (Figure $3 \mathrm{C}$ ). All data demonstrated that $\mathrm{Ni}^{2+}$ indeed inhibited SWCNTs exocytosis and as a result, leaded to more SWCNTs accumulation in cells. Furthermore, by using confocal microscopy, we further showed that, compared to SWCNTs group, more SWCNTs accumulation was observed in SWCNTs/Ni ${ }^{2+}$ treated cells (Figure 3D).

Normally, biological effects of nanoparticles are closely related to their cellular transportation and localization inside cells. We found that SWCNTs were mostly accumulated in cytoplasm and perinuclear area, and $\mathrm{Ni}^{2+}$ did not influence the distribution pattern of SWCNTs (Figure 3E). More SWCNTs were shown to be retained within cells, as shown by the flow cytometer data (Figure 3F), which further supported our SDSPAGE and UV-vis-NIR results.

Equivalent External Exposure Concentration and Toxicity of SWCNTs Due to Inhibition Effect of $\mathrm{Ni}^{2+}$. The toxicity of nanomaterials to cells, in fact, is determined by intracellular amount of nanoparticles, which, however, is to some extent dependent on external exposure concentration. Hence, to further delineate the relationship between inhibitory extent of $\mathrm{Ni}^{2+}$ and subsequent toxicity, we compared intracellular SWCNT amounts in macrophages receiving mixture exposure with those in cells exposed to different concentrations of SWCNTs ranging from 10 to $50 \mu \mathrm{g} / \mathrm{mL}$. As shown in Figure 4A, after $24 \mathrm{~h}$ exposure, the SWCNTs amount inside cells increased with increasing SWCNT exposure concentration. The intracellular SWCNTs amount for SWCNTs $/ \mathrm{Ni}^{2+}$ treatment group was approximately equivalent to that of $25 \mu \mathrm{g} / \mathrm{mL}$ SWCNTs treatment group, indicating that the presence of $\mathrm{Ni}^{2+}$ indeed influenced the internal amount of SWCNTs in macrophages. More importantly, the cell viability assay showed similar toxicity of these two groups, with $23 \%$ and $21 \%$ reduction of cell viability, respectively (Figure $4 \mathrm{~B}, p<$ $0.01)$, suggesting the elevated toxicity of SWCNTs $/ \mathrm{Ni}^{2+}$ was elicited due to increased SWCNTs accumulation in cells.

$\mathrm{P} 2 \mathrm{X}_{7} \mathrm{R}$ Mediates the Inhibitory Effects of $\mathrm{Ni}^{2+}$ on SWCNTs Exocytosis. In our recent study, we demonstrated that $\mathrm{P}_{2} \mathrm{X}_{7}$ receptor is involved in the regulation of SWCNTs exocytosis in lysosomes. ${ }^{51}$ Therefore, we hypothesized that SWCNTs exocytosis might be suppressed by $\mathrm{Ni}^{2+}$ through inactivating $\mathrm{P}_{2} \mathrm{X}_{7}$ receptor. To verify our hypothesis, an agonist (ATP) and a specific inhibitor (oATP) of $\mathrm{P}_{2} \mathrm{X}_{7}$ receptor were used. The agonist and inhibitor had no significant influence on cell viability (Figure S3). As illustrated in Figure 5A, ATP activation of $\mathrm{P} 2 \mathrm{X}_{7} \mathrm{R}$ promoted exocytosis of internalized SWCNTs from cells, leading to less retention of SWCNTs in cells compared to the control group (SWCNTs treatment alone). In contrast, oATP inhibition of $\mathrm{P}_{2} \mathrm{X}_{7} \mathrm{R}$ suppressed exocytosis of SWCNTs, resulting in more SWCNTs retained in 
A

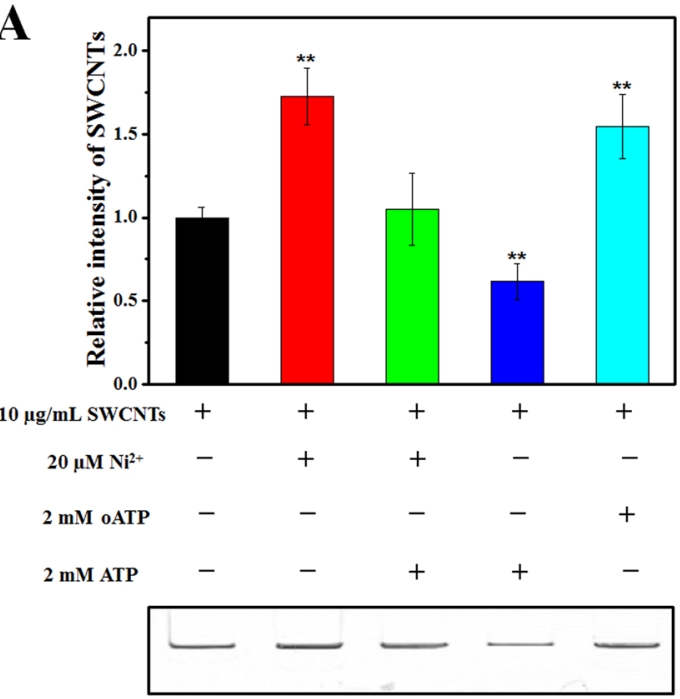

C
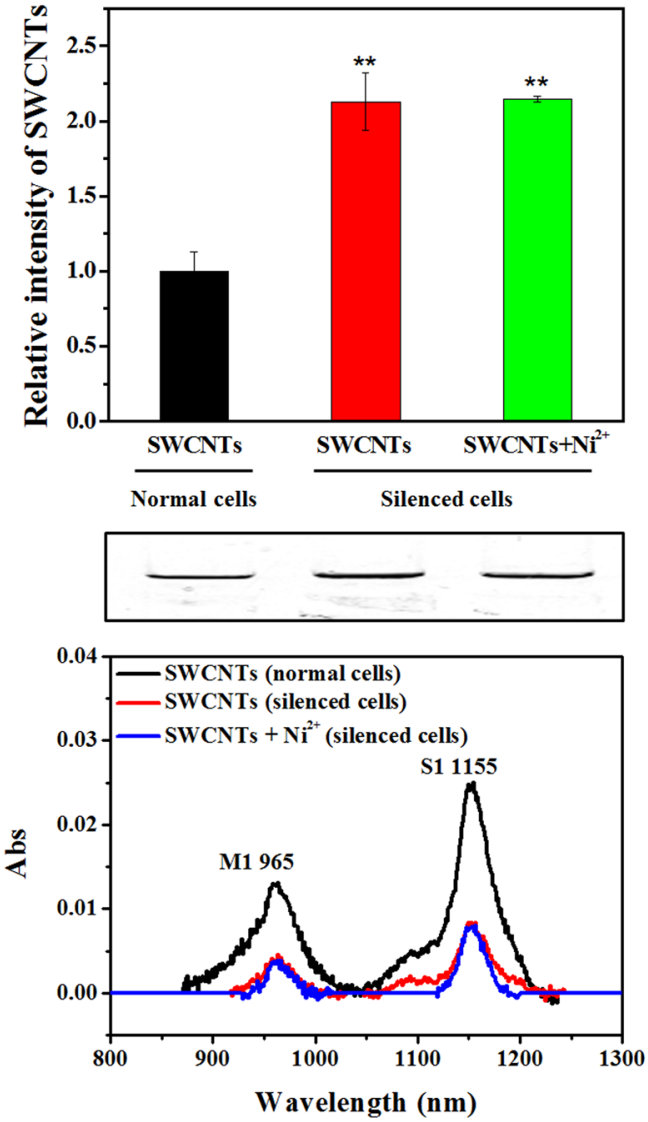

B

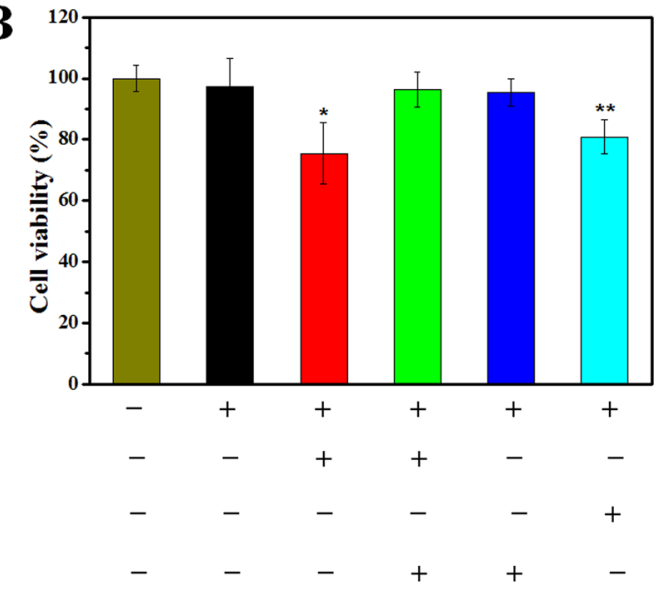

D

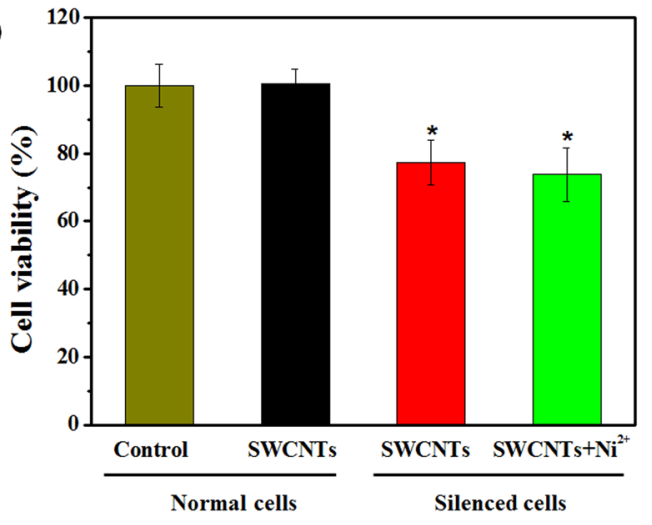

Figure 5. $\mathrm{P} 2 \mathrm{X}_{7} \mathrm{R}$ modulation on the intracellular accumulation of SWCNTs and cytotoxicity and influence of $\mathrm{P} 2 \mathrm{X}_{7} \mathrm{R}$ gene silencing on $\mathrm{SWCNTs}$ accumulation and cell survival. (A) SDS-PAGE quantification of intracellular SWCNTs in macrophages and (B) Corresponding cell viability of macrophages upon exposure to SWCNTs and SWCNTs $/ \mathrm{Ni}^{2+}$ in the presence of $\mathrm{P} 2 \mathrm{X}_{7} \mathrm{R}$ agonist and antagonist, as determined by WST-1 assay. Raw264.7 cells were pretreated with $\mathrm{P} 2 \mathrm{X}_{7} \mathrm{R}$ agonist (ATP, $2 \mathrm{mM}$ ) and $\mathrm{P} 2 \mathrm{X}_{7} \mathrm{R}$ inhibitor (oATP, $2 \mathrm{mM}$ ) for $1 \mathrm{~h}$, followed by exposure of $10 \mu \mathrm{g} / \mathrm{mL}$ SWCNTs or mixture of $10 \mu \mathrm{g} / \mathrm{mL}$ SWCNTs and $20 \mu \mathrm{M} \mathrm{Ni}^{2+}$ for $24 \mathrm{~h}$. (C) Amount of intracellular (upper panel) and extracellular (lower panel) SWCNTs in cells with (labeled with $\mathrm{P}_{2} \mathrm{X}_{7}$ siRNA) or without $\mathrm{P}_{2} \mathrm{X}_{7} \mathrm{R}$ knock-down, and (D) Corresponding cell survival after the same treatments, as determined by WST-1 assay. Quantification of SWCNTs was performed using SDS-PAGE and UV-vis-NIR. Dark bands intensity of SWCNTs in gel image was analyzed using Gelpro image software.

cells, with dramatic reduction of cell viability in comparison to the control (SWCNTs treatment only) group (Figure 5B). Similar inhibitory effect and cytotoxicity were observed in macrophages treated with $\mathrm{Ni}^{2+}$ (Figure 5A,B), indicating that
$\mathrm{Ni}^{2+}$ probably targets the same receptor $\left(\mathrm{P} 2 \mathrm{X}_{7}\right.$ receptor) as oATP on macrophages. Additionally, the increased SWCNT accumulation in SWCNTs $/ \mathrm{Ni}^{2+}$ group could be dramatically alleviated by ATP pretreatment (Figure 5A, green; Figure 5B, 

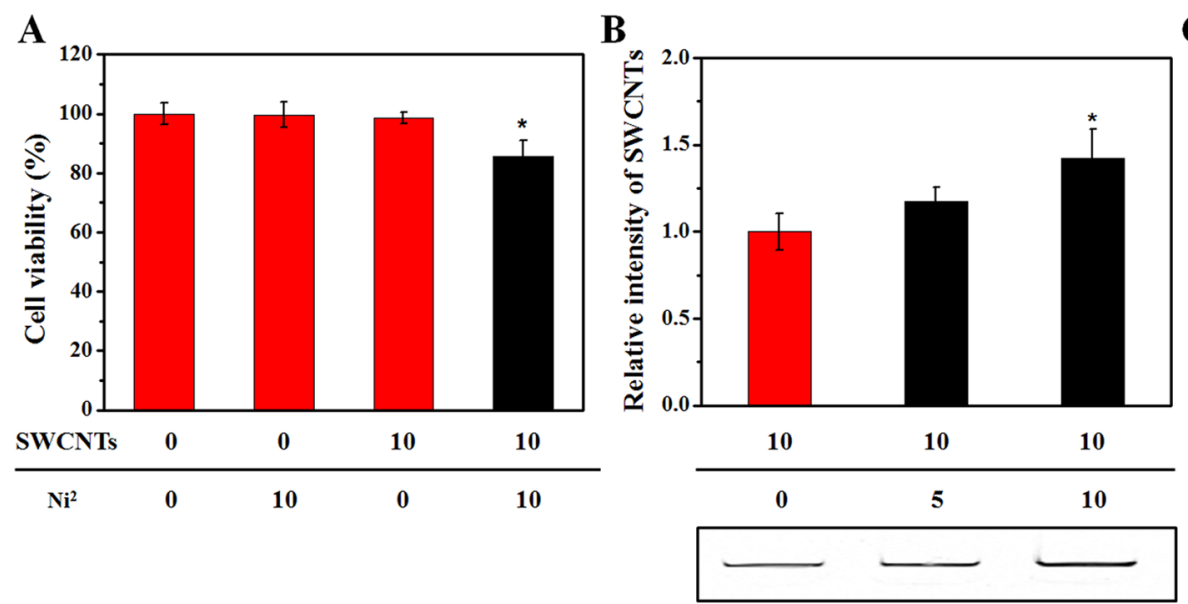

C

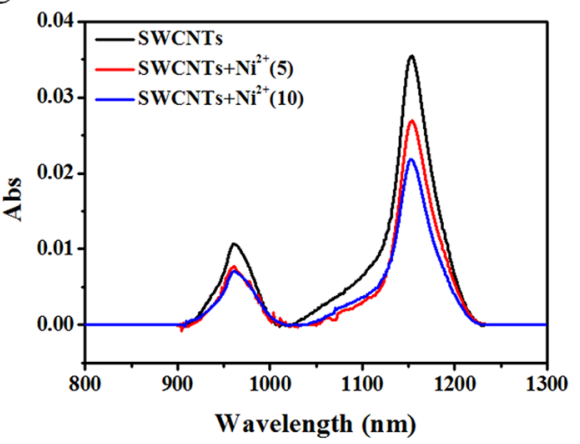

Figure 6. Cell viability, SWCNTs amount in cells and supernatants after treating THP- 1 cells with SWCNTs or a mixture of SWCNTs and Ni ${ }^{2+}$. (A) THP-1 cell viability after treatment with SWCNTs or $\mathrm{Ni}^{2+}$, alone or in combination. (B) SDS-PAGE gel (numeric data for upper panel and gel image for lower panel) and (C) UV-vis-NIR analyses of SWCNTs amount in THP-1 cells and supernatants after $24 \mathrm{~h}$ coexposure of SWCNTs and Ni ${ }^{2+}$, respectively. The intensity of the SWCNTs bands was analyzed using Gelpro software $(n=3)$.

green), suggesting that ATP played a detoxification role by activating $\mathrm{P}_{2} \mathrm{X}_{7} \mathrm{R}$ and promoting SWCNTs exocytosis. Together, these findings revealed that $\mathrm{Ni}^{2+}$ induced inhibition of SWCNTs exocytosis and the elevated toxicity of SWCNTs/ $\mathrm{Ni}^{2+}$ was probably mediated by $\mathrm{P} 2 \mathrm{X}_{7}$ receptor.

In an attempt to elucidate the crucial role of $\mathrm{P} 2 \mathrm{X}_{7}$ receptor mediating combined toxicity of SWCNTs $/ \mathrm{Ni}^{2+}$, the macrophages were transfected with a $\mathrm{P} 2 \mathrm{X}_{7}$ receptor-specific small interfering RNA (siRNA) to knockdown ${\mathrm{P} 2 \mathrm{X}_{7}}_{7}$ receptor expression. The siRNA treatment had no significant effect on cell viability (Figure S4) but decreased the expression of $\mathrm{P} 2 \mathrm{X}_{7} \mathrm{R}$ mRNA by $84 \%$ and the protein level by $88 \%$ (Figure S5). The resulting cells were used in the following experiments. To determine whether $\mathrm{Ni}^{2+}$ inhibited SWCNTs exocytosis is through targeting and blocking $\mathrm{P} 2 \mathrm{X}_{7} \mathrm{R}$, we compared the intracellular and extracellular SWCNT amount between the normal cells (without $\mathrm{P}_{2} \mathrm{X}_{7} \mathrm{R}$ siRNA treatment) and silenced cells $\left(\mathrm{P} 2 \mathrm{X}_{7} \mathrm{R}\right.$ siRNA-treated cells) after exposing them to SWCNTs or SWCNTs $/ \mathrm{Ni}^{2+}$ for $24 \mathrm{~h}$. The SDS-PAGE analyses showed that SWCNTs amount inside the silenced cells was over 2-fold more than that in the normal cells (Figure 5C), and SWCNTs exposure induced higher toxicity to the silenced cells than to the normal cells (Figure 5D). This further verified the essential role $\mathrm{P}_{2} \mathrm{X}_{7} \mathrm{R}$ plays in SWCNTs exocytosis. Furthermore, for the silenced cells, the addition of $\mathrm{Ni}^{2+}$ did not change the intracellular or extracellular SWCNTs amount and cytotoxicity in comparison to the SWCNTs treatment group (Figure 5C,D). All these data unequivocally support our hypothesis that $\mathrm{P} 2 \mathrm{X}_{7}$ receptor mediated $\mathrm{Ni}^{2+}$-induced inhibition of SWCNT exocytosis and the elevated toxicity of SWCNTs $/ \mathrm{Ni}^{2+}$ mixtures.

Confirming the Combined Toxicity and $\mathrm{Ni}^{2+}$ Inhibitory Effect on SWCNTs Exocytosis by THP-1 Cells. We further confirmed the revealed mechanism in human monocytic/macrophage cell line, THP-1, which expresses P2X $\mathrm{X}_{7} \mathrm{R}$ similarly to that of RAW264.7. THP-1 cells were induced to macrophages with PMA for $18 \mathrm{~h}(1 \mu \mathrm{g} / \mathrm{mL})$ before exposure and the macrophage cells showed no cell death upon treatment of SWCNTs $(<20 \mu \mathrm{g} / \mathrm{mL})$ and $\mathrm{Ni}^{2+}(<10 \mu \mathrm{M})$ (Figure S6), but there was about $14 \%$ viability loss when cells were exposed to a mixture of $10 \mu \mathrm{M} \mathrm{Ni}^{2+}$ and $10 \mu \mathrm{g} / \mathrm{mL}$ SWCNTs (Figure 6A), indicating that $\mathrm{Ni}^{2+}$ at $10 \mu \mathrm{M}$ dramatically aggravated the cytotoxicity of SWCNTs. In addition, the determination of intracellular and extracellular SWCNTs showed that, compared to the SWCNTs alone group, coexposure with $\mathrm{Ni}^{2+}$ increased the amount of intracellular SWCNTs (Figure 6B) and decreased the extracellular SWCNTs amount (Figure 6C) in a $\mathrm{Ni}^{2+}$ concentration-dependent manner, which further confirmed our findings that $\mathrm{Ni}^{2+}$ inhibited SWCNTs exocytosis and resulted in elevated toxicity.

The "Trojan Horse" effect ${ }^{8-13}$ was previously elucidated with a focus on the influence of nanomaterials on the toxicity/ bioavailability of environmental contaminants, while ignoring the effect of contaminants on the toxicity of nanomaterials. In contrast to previous studies, our work excluded the possibility of "Trojan Horse" effect of SWCNTs on $\mathrm{Ni}^{2+}$ toxicity, but still observed elevated toxicity of SWCNTs in the presence of $\mathrm{Ni}^{2+}$ at nontoxic doses. In this work, we revealed a novel mechanism for the combined toxicity of nanomaterial/chemical mixtures in which $\mathrm{Ni}^{2+}$, by blocking the activation of $\mathrm{P} 2 \mathrm{X}_{7} \mathrm{R}$, inhibited SWCNTs exocytosis, resulting in increased intracellular accumulation of the nanotubes and higher toxicity. Our study suggests that, in the evaluation of the combined toxicity of nanomaterials and chemicals, modulation on the toxic-kinetics of chemicals by nanomaterials as well as the nanomaterials by chemicals need to be investigated in a balanced fashion so as to gain a full picture of the underlying mechanisms.

In a way, the interactive effects of nanomaterial/chemical mixtures are similar to drug-drug interactions in pharmaceutical science, in which one pharmaceutical chemical interacts in vivo with another one and attenuates either the therapeutic efficacy or clinical toxicity of the latter. The drug interactions occur through the alteration of either drug-metabolizing enzymes or cell membrane transporters. Until now, two major classes of transporters have been found to mediate drug interactions, that is, $\mathrm{ABC}$ family (such as P-glycoprotein) and SLC family (such as OATP1B1). ${ }^{52}$ The most important finding of this study is that we identified another membrane protein, $\mathrm{P} 2 \mathrm{X}_{7} \mathrm{R}$, as the mediator involved in SWCNTs-Ni ${ }^{2+}$ interactions. $\mathrm{P} 2 \mathrm{X}_{7} \mathrm{R}$ is an extracellular ATP-gated ion channel protein highly expressed on the plasma membrane of neurons and immune cells including $\mathrm{T}$ cells, dendritic cells, and monocytes/macrophages. ${ }^{48}$ This unique receptor was shown 
to mediate the inflammatory response as well as the release of secretory lysosomes in macrophages. ${ }^{41,42}$ In addition to $\mathrm{Ni}^{2+}$, some other heavy metals including copper and cadmium ions were both shown to inhibit $\mathrm{P}_{2} \mathrm{X}_{7} \mathrm{R}^{39,53}$ Therefore, the mechanism revealed in this work with the SWCNTs $/ \mathrm{Ni}^{2+}$ mixtures may be also applicable to $\mathrm{Cu}^{2+}, \mathrm{Cd}^{2+}$, and possibly other chemicals which inhibit $\mathrm{P} 2 \mathrm{X}_{7} \mathrm{R}$.

Nickel and nickel compounds are used in many industrial products such as stainless steel and nickel alloys, catalysts, and pigments. ${ }^{5,55}$ Some evidence demonstrated that metalcontaining SWCNTs are likely more toxic than the metal-free nanotubes. ${ }^{27,56} \mathrm{~A}$ well accepted explanation is that transition metals (including nickel) react with hydrogen peroxides in cells and produce large amount of reactive oxygen species (ROS), which are detrimental to cells. Here, our findings would suggest that residual metal ions released from SWCNTs during SWCNT modification such as acid purification, might act as an exocytosis inhibitor of SWCNTs and aggravate the toxicity of SWCNTs.

The present study has verified that $\mathrm{Ni}^{2+}$ altered the biological fate of SWCNTs -exocytosis in macrophages through blocking membrane receptor- $\mathrm{P} 2 \mathrm{X}_{7} \mathrm{R}$. However, the precise mechanisms have not been clearly recognized to date. We speculate that there are three possibilities. First of all, $\mathrm{Ni}^{2+}$ binds directly to the extracellular domain of $\mathrm{P} 2 \mathrm{X}_{7} \mathrm{R}$ and induces allosteric change of $\mathrm{P} 2 \mathrm{X}_{7} \mathrm{R}$, resulting in $\mathrm{P} 2 \mathrm{X}_{7} \mathrm{R}$ malfunction. Alternatively, $\mathrm{Ni}^{2+}$ interferes directly with the downstream signaling of $\mathrm{P} 2 \mathrm{X}_{7} \mathrm{R}$ such as $\mathrm{Ca}^{2+}$ influx. And third, $\mathrm{Ni}^{2+}$ competes the receptor binding sites with $\mathrm{ATP}$, an activator and natural ligand of $\mathrm{P} 2 \mathrm{X}_{7} \mathrm{R}$, thus numbs $P 2 X_{7} R$. The answer to these questions would provide a better understanding of the initial molecular events for the inhibition of $\mathrm{P} 2 \mathrm{X}_{7} \mathrm{R}$, which warrants detailed investigation in the future.

In summary, the findings of this work demonstrated that noncytotoxic level of $\mathrm{Ni}^{2+}$ and SWCNTs exhibited elevated toxicity to macrophages in combination. The underlying mechanism was revealed to be that $\mathrm{Ni}^{2+}$ inhibits the activation of $\mathrm{P}_{2} \mathrm{X}_{7}$ receptor, which is required for the exocytosis of SWCNTs, leading to accumulation of intracellular SWCNTs and higher toxicity. The findings highlight the importance of evaluating the risks of mixtures in addition to single chemical/ contaminant, and suggest caution in case of possible coexistence or sequential exposure of $\mathrm{Ni}^{2+}$ and SWCNTs in environment because nontoxic exposure levels of $\mathrm{Ni}^{2+}$ and SWCNTs might induce adverse health outcomes in the mixture. Furthermore, our data underscore the challenge of predicting environmental risks posed by nanomaterials, which requires careful integration of complex interactions between nanomaterials and contaminants.

\section{ASSOCIATED CONTENT}

\section{S Supporting Information}

The Supporting Information is available free of charge on the ACS Publications website at DOI: 10.1021/acs.est.6b03842

Figures showing the characterization of SWCNTs by TEM, FT-IR, Raman; cell viability under the treatment with a series concentrations of $\mathrm{Ni}^{2+}$; cell viability after treatment with ATP and oATP; cell viability after treatment with $\mathrm{P}_{2} \mathrm{X}_{7} \mathrm{R}$ siRNA and negative control; and relative mRNA level and protein level $d$ of $P 2 X_{7} R$ after $\mathrm{P} 2 \mathrm{X}_{7} \mathrm{R}$ siRNA treatment; cell viability of THP-1 cells under the treatment of $\mathrm{Ni}^{2+}$ and SWCNTs (PDF)

\section{AUTHOR INFORMATION}

\section{Corresponding Authors}

*(B.W.) Phone: (86) 10-62849338; fax: (86) 10-62849685; email: binwan@rcees.ac.cn.

*(L.-H.G.) E-mail: LHGuo@rcees.ac.cn.

\section{Notes}

The authors declare no competing financial interest.

\section{ACKNOWLEDGMENTS}

This work was supported by the Chinese Academy of Sciences (XDB14040101), Key Research Program of Frontier Sciences, CAS (QYZDJ-SSW-DQC020-02) and National Natural Science Foundation of China (21477146, 21277158, 91543203, 21321004, 21577163, 21407168).

\section{REFERENCES}

(1) Gardner, H. S.; Brennan, L. M.; Toussaint, M. W.; Rosencrance, A. B.; Boncavage-Hennessey, E. M.; Wolfe, M. J. Environmental complex mixture toxicity assessment. Environ. Health. Persp. 1998, 106, 1299-1305.

(2) Mauderly, J. L.; Samet, J. M. Is There Evidence for Synergy Among Air Pollutants in Causing Health Effects? Environ. Health. Persp. 2009, 117, 1-6.

(3) Krishnan, K.; Brodeur, J. Toxic Interactions Among Environmental-Pollutants - Corroborating Laboratory Observations With Human-Experience. Environ. Health. Persp. 1994, 102, 11-17.

(4) Balbi, T.; Smerilli, A.; Fabbri, R.; Ciacci, C.; Montagna, M.; Grasselli, E.; Brunelli, A.; Pojana, G.; Marcomini, A.; Gallo, G. Coexposure to $\mathrm{n}-\mathrm{TiO}_{2}$ and $\mathrm{Cd}^{2+}$ results in interactive effects on biomarker responses but not in increased toxicity in the marine bivalve M. galloprovincialis. Sci. Total Environ. 2014, 493, 355-364.

(5) Zhang, L.; Hu, C.; Wang, W.; Ji, F.; Cui, Y.; Li, M. Acute toxicity of multi-walled carbon nanotubes, sodium pentachlorophenate, and their complex on earthworm Eisenia fetida. Ecotoxicol. Environ. Saf. 2014, 103, 29-35.

(6) Azevedo Costa, C. L.; Chaves, I. S.; Ventura-Lima, J.; Ferreira, J. L. R.; Ferraz, L.; de Carvalho, L. M.; Monserrat, J. M. In vitro evaluation of co-exposure of arsenium and an organic nanomaterial (fullerene, $\mathrm{C}_{60}$ ) in zebrafish hepatocytes. Comp. Biochem. Physiol., Part C: Toxicol. Pharmacol. 2012, 155, 206-12.

(7) Chen, J.; Qian, Y.; Li, H.; Cheng, Y.; Zhao, M. The reduced bioavailability of copper by nano- $\mathrm{TiO}_{2}$ attenuates the toxicity to Microcystis aeruginosa. Environ. Sci. Pollut. Res. 2015, 22, 12407-14.

(8) Ferreira, J. L. R.; Lonné, M. N.; França, T. A.; Maximilla, N. R.; Lugokenski, T. H.; Costa, P. G.; Fillmann, G.; Soares, F. A. A.; Torre, F. R. D. L.; Monserrat, J. M. Co-exposure of the organic nanomaterial fullerene $\mathrm{C}_{60}$ with benzo[a]pyrene in Danio rerio (zebrafish) hepatocytes: Evidence of toxicological interactions. Aquat. Toxicol. 2013, 147C, 76-83.

(9) Tian, S.; Zhang, Y.; Song, C.; Zhu, X.; Xing, B. Titanium dioxide nanoparticles as carrier facilitate bioaccumulation of phenanthrene in marine bivalve, ark shell (Scapharca subcrenata). Environ. Pollut. 2014, 192, 59-64.

(10) Tian, S.; Zhang, Y.; Song, C.; Zhu, X.; Xing, B. Bioaccumulation and biotransformation of polybrominated diphenyl ethers in the marine bivalve (Scapharca subcrenata): Influence of titanium dioxide nanoparticles. Mar. Pollut. Bull. 2015, 90, 48-53.

(11) Zhu, X.; Zhou, J.; Cai, Z. $\mathrm{TiO}_{2}$ Nanoparticles in the Marine Environment: Impact on the Toxicity of Tributyltin to Abalone (Haliotis diversicolor supertexta) Embryos. Environ. Sci. Technol. 2011, 45, 3753-3758.

(12) Fan, W.; Cui, M.; Liu, H.; Wang, C.; Shi, Z.; Tan, C.; Yang, X. Nano- $\mathrm{TiO}_{2}$ enhances the toxicity of copper in natural water to Daphnia magna. Environ. Pollut. 2011, 159, 729-734.

(13) Miao, W.; Zhu, B.; Xiao, X.; Li, Y.; Dirbaba, N. B.; Zhou, B.; $\mathrm{Wu}, \mathrm{H}$. Effects of titanium dioxide nanoparticles on lead bioconcentration and toxicity on thyroid endocrine system and 
neuronal development in zebrafish larvae. Aquat. Toxicol. 2015, 161, $117-126$.

(14) Hu, C.; Cai, Y.; Wang, W.; Cui, Y.; Li, M. Toxicological effects of multi-walled carbon nanotubes adsorbed with nonylphenol on earthworm Eisenia fetida. Environ. Sci. Processes Impacts 2013, 15, $2125-2130$.

(15) Kim, K. T.; Klaine, S. J.; Lin, S. J.; Ke, P. C.; Kim, S. D. Acute toxicity of a mixture of copper and single-walled carbon nanotubes to daphnia magna. Environ. Toxicol. Chem. 2010, 29, 122-126.

(16) Martinez, D. S. T.; Alves, O. L.; Barbieri, E.; Iop Carbon Nanotubes Enhanced the Lead Toxicity on the Freshwater Fish. In Nanosafe 2012: International Conferences on Safe Production and Use of Nanomaterials, 2013.

(17) Yan, L.; Feng, M.; Liu, J.; Wang, L.; Wang, Z. Antioxidant defenses and histological changes in Carassius auratus after combined exposure to zinc and three multi-walled carbon nanotubes. Ecotoxicol. Environ. Saf. 2016, 125, 61-71.

(18) Qu, R.; Wang, X.; Wang, Z.; Wei, Z.; Wang, L. Metal accumulation and antioxidant defenses in the freshwater fish Carassius auratus in response to single and combined exposure to cadmium and hydroxylated multi-walled carbon nanotubes. J. Hazard. Mater. 2014, 275, 89-98.

(19) Fang, Q.; Shi, X.; Zhang, L.; Wang, Q.; Wang, X.; Guo, Y.; Zhou, B. Effect of titanium dioxide nanoparticles on the bioavailability, metabolism, and toxicity of pentachlorophenol in zebrafish larvae. $J$. Hazard. Mater. 2015, 283, 897-904.

(20) Baughman, R. H.; Zakhidov, A. A.; de Heer, W. A. Carbon nanotubes-the route toward applications. Science 2002, 297, 787-92.

(21) De Volder, M. F. L.; Tawfick, S. H.; Baughman, R. H.; Hart, A. J. Carbon Nanotubes: Present and Future Commercial Applications. Science 2013, 339, 535-539.

(22) Boczkowski, J.; Lanone, S. Respiratory toxicities of nanomaterials - A focus on carbon nanotubes. Adv. Drug Delivery Rev. 2012, 64, 1694-1699.

(23) Smith, C. J.; Shaw, B. J.; Handy, R. D. Toxicity of single walled carbon nanotubes to rainbow trout, (Oncorhynchus mykiss): Respiratory toxicity, organ pathologies, and other physiological effects. Aquat. Toxicol. 2007, 82, 94-109.

(24) Yang, S. T.; Guo, W.; Lin, Y.; Deng, X. Y.; Wang, H. F.; Sun, H. F.; Liu, Y. F.; Wang, X.; Wang, W.; Chen, M.; Huang, Y. P.; Sun, Y. P. Biodistribution of pristine single-walled carbon nanotubes in vivo. J. Phys. Chem. C 2007, 111, 17761-17764.

(25) Lam, C. W.; James, J. T.; McCluskey, R.; Hunter, R. L. Pulmonary toxicity of single-wall carbon nanotubes in mice 7 and 90 days after intratracheal instillation. Toxicol. Sci. 2004, 77, 126-134.

(26) Shvedova, A. A.; Kisin, E. R.; Mercer, R.; Murray, A. R.; Johnson, V. J.; Potapovich, A. I.; Tyurina, Y. Y.; Gorelik, O.; Arepalli, S.; Schwegler-Berry, D.; Hubbs, A. F.; Antonini, J.; Evans, D. E.; Ku, B. K.; Ramsey, D.; Maynard, A.; Kagan, V. E.; Castranova, V.; Baron, P. Unusual inflammatory and fibrogenic pulmonary responses to singlewalled carbon nanotubes in mice. Am. J. Physiol: Lung Cel. Mol. Physiol. 2005, 289, L698-L708.

(27) Manna, S. K.; Sarkar, S.; Barr, J.; Wise, K.; Barrera, E. V.; Jejelowo, O.; Rice-Ficht, A. C.; Ramesh, G. T. Single-Walled Carbon Nanotube Induces Oxidative Stress and Activates Nuclear Transcription Factor-KB in Human Keratinocytes. Nano Lett. 2005, 5 (9), $1676-1684$.

(28) Magrez, A.; Kasas, S.; Salicio, V.; Pasquier, N.; Seo, J. W.; Celio, M.; Catsicas, S.; Schwaller, B.; Forro, L. Cellular toxicity of carbonbased nanomaterials. Nano Lett. 2006, 6, 1121-1125.

(29) Cui, D.; Tian, F.; Ozkan, C. S.; Wang, M.; Gao, H. Effect of single wall carbon nanotubes on human HEK293 cells. Toxicol. Lett. 2005, 155, 73-85.

(30) Mooney, E.; Dockery, P.; Greiser, U.; Murphy, M.; Barron, V. Carbon nanotubes and mesenchymal stem cells: Biocompatibility, proliferation and differentiation. Nano Lett. 2008, 8, 2137-2143.

(31) Herzog, E.; Casey, A.; Lyng, F. M.; Chambers, G.; Byrne, H. J.; Davoren, M. A new approach to the toxicity testing of carbon-based nanomaterials - The clonogenic assay. Toxicol. Lett. 2007, 174, 49-60.
(32) Dong, P. X.; Wan, B.; Guo, L. H. In vitro toxicity of acidfunctionalized single-walled carbon nanotubes: effects on murine macrophages and gene expression profiling. Nanotoxicology 2012, 6, 288-303.

(33) Witasp, E.; Shvedova, A. A.; Kagan, V. E.; Fadeel, B. Singlewalled carbon nanotubes impair human macrophage engulfment of apoptotic cell corpses. Inhalation Toxicol. 2009, 21 (Suppl 1), 131-6.

(34) Dong, P. X.; Wan, B.; Wang, Z. X.; Guo, L. H.; Yang, Y.; Zhao, L. Exposure of single-walled carbon nanotubes impairs the functions of primarily cultured murine peritoneal macrophages. Nanotoxicology 2013, 7, 1028-42.

(35) IARC. IARC Monographs on the Evaluation of Carcinogenic Risks to Humans. Chromium, Nickel and Welding. Food Chem. Toxicol. 1990, 49, 257-445.

(36) Costa, M.; Davidson, T. L.; Chen, H. B.; Ke, Q. D.; Zhang, P.; Yan, Y.; Huang, C. S.; Kluz, T. Nickel carcinogenesis: Epigenetics and hypoxia signaling. Mutat. Res., Fundam. Mol. Mech. Mutagen. 2005, 592, 79-88.

(37) Zhang, Y.; Zhang, Z. W.; Xie, Y. M.; Wang, S. S.; Qiu, Q. H.; Zhou, Y. L.; Zeng, G. H. Toxicity of nickel ions and comprehensive analysis of nickel ion-associated gene expression profiles in THP-1 cells. Mol. Med. Rep. 2015, 12, 3273-3278.

(38) Marchetti, C. Interaction of metal ions with neurotransmitter receptors and potential role in neurodiseases. BioMetals 2014, 27, $1097-1113$

(39) Virginio, C.; Church, D.; North, R. A.; Surprenant, A. Effects of divalent cations, protons and calmidazolium at the rat $\mathrm{P} 2 \mathrm{X}(7)$ receptor. Neuropharmacology 1997, 36, 1285-1294.

(40) Watano, T.; Matsuoka, I.; Kimura, J. Inhibitory effects of metals on ATP-induced current through P2X(7) receptor in NG108-15 cells. Jpn. J. Pharmacol. 2002, 89, 296-301.

(41) Adinolfi, E.; Pizzirani, C.; Idzko, M.; Panther, E.; Norgauer, J.; Di Virgilio, F.; Ferrari, D. P2X(7) receptor: Death or life? Purinergic Signalling 2005, 1, 219-27.

(42) Dubyak, G. R. P2 $\times 7$ receptor regulation of non-classical secretion from immune effector cells. Cell. Microbiol. 2012, 14, 16971706.

(43) Qu, Y.; Franchi, L.; Nunez, G.; Dubyak, G. R. Nonclassical IL-1 Secretion Stimulated by $\mathrm{P} 2 \times 7$ Receptors Is Dependent on Inflammasome Activation and Correlated with Exosome Release in Murine Macrophages. J. Immunol. 2007, 179, 1913-1925.

(44) Qu, Y.; Dubyak, G. R. P2 $\times 7$ receptors regulate multiple types of membrane trafficking responses and non-classical secretion pathways. Purinergic Signalling 2009, 5, 163-173.

(45) Moore, M. N.; Readman, J. A.; Readman, J. W.; Lowe, D. M.; Frickers, P. E.; Beesley, A. Lysosomal cytotoxicity of carbon nanoparticles in cells of the molluscan immune system: an in vitro study. Nanotoxicology 2009, 3, 40-45.

(46) Tahara, Y.; Nakamura, M.; Yang, M.; Zhang, M.; Iijima, S.; Yudasaka, M. Lysosomal membrane destabilization induced by high accumulation of single-walled carbon nanohorns in murine macrophage RAW 264.7. Biomaterials 2012, 33, 2762-9.

(47) Wan, B.; Wang, Z. X.; Lv, Q. Y.; Dong, P. X.; Zhao, L. X.; Yang, Y.; Guo, L. H. Single-walled carbon nanotubes and graphene oxides induce autophagosome accumulation and lysosome impairment in primarily cultured murine peritoneal macrophages. Toxicol. Lett. 2013, $221,118-127$.

(48) Volonté, C.; Apolloni, S.; Skaper, S. D.; Burnstock, G. P2 $\times 7$ Receptors:Channels, Pores and More. CNS Neurol. Disord.: Drug Targets 2012, 11.70510.2174/187152712803581137

(49) Wang, R. H.; Mikoryak, C.; Chen, E.; Li, S.; Pantano, P.; Draper, R. K. Gel Electrophoresis Method to Measure the Concentration of Single-Walled Carbon Nanotubes Extracted from Biological Tissue. Anal. Chem. 2009, 81, 2944-2952.

(50) Ngamwongsatit, P.; Banada, P. P.; Panbangred, W.; Bhunia, A. K. WST-1-based cell cytotoxicity assay as a substitute for MTT-based assay for rapid detection of toxigenic Bacillus species using $\mathrm{CHO}$ cell line. J. Microbiol. Methods 2008, 73, 211-215. 
(51) Cui, X. J.; Wan, B.; Yang, Y.; Ren, X. M.; Guo, L. H.; Zhang, H. Crucial Role of P $2 \times 7$ Receptor in Regulating Exocytosis of SingleWalled Carbon Nanotubes in Macrophages. Small 2016, DOI: $10.1002 /$ smll.201602410.

(52) Zhang, L.; Reynolds, K. S.; Zhao, P.; Huang, S.-M. Drug interactions evaluation: An integrated part of risk assessment of therapeutics. Toxicol. Appl. Pharmacol. 2010, 243, 134-145.

(53) Jiang, L. H. Inhibition of P2X(7) receptors by divalent cations: old action and new insight. Eur. Biophys. J. 2009, 38, 339-346.

(54) Mazinanian, N.; Hedberg, Y.; Odnevall Wallinder, I. Nickel release and surface characteristics of fine powders of nickel metal and nickel oxide in media of relevance for inhalation and dermal contact. Regul. Toxicol. Pharmacol. 2013, 65, 135-146.

(55) Denkhaus, E.; Salnikow, K. Nickel essentiality, toxicity, and carcinogenicity. Crit. Rev. Oncology/hematology 2002, 42, 35-56.

(56) Gorelik, O. P.; Nikolaev, P.; Arepalli, S.; Gorelik, O. P. Purification Procedures for Single-Wall Carbon Nanotubes-NASA/ CR-2000-208926 Nasa Contractor Report.nasa Cr.united States.national Aeronautics Space Administration, 2000. 